Brit. Heart F., 1966, 28, 179.

\title{
The A Wave of the Apex Cardiogram in Idiopathic Hypertrophic Subaortic Stenosis
}

\author{
ALLAN D. WOLFE \\ From the Department of Cardiology, St. Vincent's Hospital, Los Angeles, California, U.S.A.
}

Idiopathic hypertrophic subaortic stenosis was first clearly described as a clinical entity by Brock in 1957. Since then its specific clinical aspects have been reviewed among others by Braunwald et al. in 1964. The condition is characterized by hypertrophy of the left ventricle, and particularly of the ventricular septum. The left ventricular cavity is small and its outflow tract narrowed by hypertrophy of the musculature in the subvalvular region.

Low frequency præcordial pulsations, which are inaudible, were recorded by Marey as early as 1878 , and represent the impulse felt at the apex of the heart. A review of present-day methods of recording these low frequencies was made by Agress et al., in 1964, the records obtained being either displacement (first derivative) or acceleration (second derivative) tracings.

At least three methods of recording displacement tracings are available: the apex cardiogram (Benchimol and Dimond, 1963a), the kinetocardiogram (Eddleman et al., 1953), and the method of Beilin and Mounsey (1962). Reviews of recent studies of apex cardiograms have been made (Rörvik, 1963; Benchimol and Dimond, 1963a).

It is the purpose of this paper to describe the changes in the apex cardiogram in muscular subaortic stenosis, and of particular interest has been the increase in size of the A wave.

\section{SubJeCts AND Methods}

The apex cardiogram was obtained according to the procedure of Hartman and Snellen (1960), and Benchimol and Dimond (1963a). The apex cardiogram indicates displacement over the apex of the heart; the frequencies are in the range of 0.1 to 50 cycles per second and are below the frequency audible by means of the stethoscope. The records were taken with the patient lying

Received March 12, 1965. in the left lateral position with the pick-up bell placed over the point of maximum impulse of the heart, as felt with the palm of the hand. The microphone was usually held by the person taking the record. The patient was told to hold his breath temporarily in midexpiration. Most of the records were obtained at a paper speed of $75 \mathrm{~mm}$./second; occasionally $100 \mathrm{~mm}$./ second was used.

The A wave occurs just before the QRS wave of the electrocardiogram and about $0 \cdot 10$ second after the beginning of the $P$ wave. It is measured from the end of the slow filling wave and the width normally measures 0.02 to 0.05 second. The $A$ wave ratio is the percentage height of the $A$ wave in relation to the total height of the record, measured vertically from the $E$ point to the $O$ point. The AE interval is measured from the peak of the $\mathrm{A}$ wave to the $\mathrm{E}$ point, and varies from 0.03 to 0.28 second, in normal subjects. The isometric contraction time is measured from the end of the $A$ wave to the $\mathbf{E}$ point, and its normal duration is 0.03 to 0.06 second. The rapid filling wave ratio is the percentage height of the rapid filling wave to the total amplitude, measured vertically from the $E$ point to the $O$ point. It is normally 20 to 40 per cent, with a duration of 0.04 to 0.08 second. The $\mathrm{E}$ point is the point of aortic valve opening. The $O$ point is the point of mitral valve opening.

The apex cardiograms of 9 patients in whom the diagnosis of muscular subaortic stenosis had been proved by means of catheterization were studied.

\section{RESUITS}

The records obtained in our 9 patients are reproduced in the Figure. The data in these patients are presented in the Table. It is seen that the $A$ wave amplitude ratio in the apex cardiogram (ACG) was increased to an unusual degree in 8 of the 9 (average $28.1 \%$ ). The $A$ wave was abnormally wide in 7 of the 8 patients in whom it could be measured. A late systolic bulge was seen in 2 of 
FIG. 1.-Apex cardiograms in 9 patients with subaortic stenosis. Large A wave amplitudes are seen in all records except E.E. Records were taken at a paper speed of $75 \mathrm{~mm}$./sec. except in J.P., which was taken at a paper speed of $100 \mathrm{~mm}$./sec. The time interval of lines was $0.1 \mathrm{sec}$. $/ \mathrm{min}$., except in L.W. where it was 0.20 $\mathrm{sec}$. $/ \mathrm{min}$., and in L.N. where it was $0.05 \mathrm{sec}$. $/ \mathrm{min}$. The phonocardiograms and apex cardiograms are recorded at the point of maximum impulse of the left ventricle. The measurements of the apex cardiograms are recorded in the Table. The initials of the patients in this Figure correspond to those in the Table. ECG, electrocardiogram; ACG, apex cardiogram; Phono, phonocardiogram. 
TABLE

APEX CARDIOGRAM IN IDIOPATHIC SUBAORTIC STENOSIS AND RELATION TO LEFT-SIDED PRESSURES

\begin{tabular}{|c|c|c|c|c|c|c|c|c|c|c|c|}
\hline & & \multicolumn{4}{|c|}{ A wave } & Systole & \multicolumn{2}{|c|}{ Diastole } & \multicolumn{3}{|c|}{ Pressure (mm. Hg) } \\
\hline \multicolumn{2}{|c|}{$\begin{array}{c}\text { Patient, age (yr.), } \\
\text { and sex }\end{array}$} & $\begin{array}{l}\text { Width } \\
\text { of A } \\
\text { wave }\end{array}$ & $\begin{array}{c}\text { A wave } \\
\text { ratio } \\
(\%)\end{array}$ & $\begin{array}{l}\text { Peak A } \\
\text { to E time } \\
\text { interval }\end{array}$ & $\begin{array}{c}\text { Isometric } \\
\text { contrac- } \\
\text { tion time } \\
\text { nadir of } \\
\mathrm{A} \text { to } \mathrm{E}\end{array}$ & $\begin{array}{l}\text { Systolic } \\
\text { bulge }\end{array}$ & $\begin{array}{c}\text { Rapid } \\
\text { filling } \\
\text { wave } \\
\text { ratio } \\
(\%)\end{array}$ & $\begin{array}{c}\text { Duration } \\
\text { of rapid } \\
\text { filling wave } \\
\text { (sec.) }\end{array}$ & $\begin{array}{c}\text { LV } \\
\text { end- } \\
\text { diastolic }\end{array}$ & $\begin{array}{l}\text { Systolic } \\
\text { gradient } \\
\text { in LV }\end{array}$ & \begin{tabular}{|c|} 
LV \\
systolic \\
pressure \\
below ob- \\
struction
\end{tabular} \\
\hline & & $\begin{array}{l}\text { Normal } \\
\text { values } \\
0.02- \\
0.05 \\
\text { sec. }\end{array}$ & $\begin{array}{l}0- \\
13\end{array}$ & $\begin{array}{l}0.03- \\
0.28\end{array}$ & $\begin{array}{l}0.03- \\
0.06\end{array}$ & - & $\begin{array}{l}20- \\
40\end{array}$ & $\begin{array}{l}0.04- \\
0.08\end{array}$ & & & \\
\hline L. N. 55 & $M$ & $0 \cdot 12$ & 43 & $0 \cdot 14$ & 0.08 & + & 28 & 0.07 & 12 & 14 & 160 \\
\hline Le. G. 26 & $\mathbf{M}$ & $0 \cdot 13$ & 66 & $0 \cdot 14$ & 0.09 & $\begin{array}{l}\text { Late systole } \\
+ \\
\text { Mid }\end{array}$ & 14 & 0.07 & 25 & 78 & 173 \\
\hline R. C. 24 & $\mathbf{M}$ & $0 \cdot 10$ & 41 & $0 \cdot 14$ & 0.08 & $\begin{array}{c}\text { Mid-systole } \\
+ \\
\end{array}$ & 40 & 0.07 & 30 & 107 & 215 \\
\hline E. E. 37 & $\mathbf{M}$ & $\begin{array}{c}\text { Not } \\
\text { measur- } \\
\text { able }\end{array}$ & 0 & $\begin{array}{c}\text { Not } \\
\text { measur- } \\
\text { able }\end{array}$ & $\begin{array}{l}\text { Not } \\
\text { measur- } \\
\text { able }\end{array}$ & $\begin{array}{c}+ \\
\text { Intermittent } \\
\text { mid-systole }\end{array}$ & 35 & $0 \cdot 12$ & 18 & 0 * & 135 \\
\hline $\begin{array}{ll}\text { G. B. } & 47 \\
\text { L. W. } & 33 \\
\text { J. P. } & 65 \\
\text { J. W. } & 27 \\
\text { E. H. } & 19\end{array}$ & $\begin{array}{l}\mathbf{F} \\
\mathbf{M} \\
\mathbf{M} \\
\mathbf{F} \\
\mathbf{M}\end{array}$ & $\begin{array}{l}0.10 \\
0.06 \\
0.04 \\
0.12 \\
0.07\end{array}$ & $\begin{array}{l}18 \\
35 \\
14 \\
24 \\
12\end{array}$ & $\begin{array}{l}0.12 \\
0.12 \\
0.15 \\
0.12 \\
0.10\end{array}$ & $\begin{array}{l}0.09 \\
0.08 \\
0.12 \\
0.10 \\
0.08\end{array}$ & = & $\begin{array}{l}50 \\
42 \\
29 \\
37 \\
57\end{array}$ & $\begin{array}{l}0.20 \\
0.07 \\
0.07 \\
0.10 \\
0.12\end{array}$ & $\begin{array}{r}40 \\
20 \\
0 \\
19 \\
22\end{array}$ & $\begin{array}{l}60 \\
42 \\
40 \\
18 \\
56\end{array}$ & $\begin{array}{l}160 \\
160 \\
180 \\
102 \\
162\end{array}$ \\
\hline
\end{tabular}

LV, left ventricle.

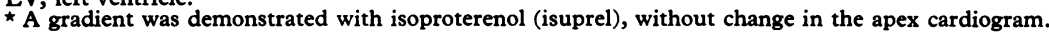

the 9 , and a mid-systolic bulge in 2 ; in one of these the bulge was intermittent (or the record was faulty) (Fig. 1 E.E.). The most distinctive feature of the apex cardiogram in subaortic stenosis was the tall wide $\mathrm{A}$ wave which produces a clinically palpable double apex pulsation.

\section{Discussion}

Amplitude. The A wave, though small, is frequently present in normal individuals. It was encountered in 55 per cent of 60 normal subjects examined by Rörvik in 1963. In 52 normal subjects with an average age of 36 years (age range 5 to 64 years), it measured 7.8 per cent \pm 1.4 per cent of the total amplitude of the tracing (Benchimol and Dimond, 1962). In a subsequent series of patients with an average age of 54.6 years (age range 40 to 84 years) by the same authors, it measured 10 per cent \pm 3.6 per cent. With exercise this value increased to 12 per cent of the total amplitude, a very slight change. Tracings usually show a positive wave for left atrial contraction, occasionally preceded by a negative wave for right atrial contraction (Luisada and Magri, 1952).

The largest A waves seem to occur in hypertrophic subaortic stenosis. Tafur, Cohen, and Levine (1964) reported tall peaked A waves in 4 out of 6 patients with idiopathic hypertrophic stenosis; the values were not given. Braunwald et al. (1964) reported that the A wave ratio was abnormally raised in 38 out of 43 patients, with an average value of 28.8 per cent and a range between 4.2 per cent and 81 per cent. In patients with coronary disease the $A$ wave may be increased in size. In a series of 45 patients, 45 per cent had $A$ waves of normal amplitude, but in 55 per cent the waves were of increased size, averaging 22 per cent \pm 8.1 per cent of the total amplitude (Benchimol and Dimond, 1963b). In 1963 Rörvik found that 13 per cent of his 131 patients with coronary disease had an $A$ wave greater than 30 per cent. In 5 of our patients with valvular aortic stenosis, the highest value was 17 per cent. Only in 1 of 8 cases of aortic regurgitation did the value prove to be abnormal, and in that instance it was 18 per cent. In mitral stenosis and mitral regurgitation, the $A$ wave is small; one of two cases of primary pulmonary hypertension demonstrated an abnormal A wave (38\%). None of our 7 patients with hyperthyroidism showed abnormal A waves. A patient with virus myocarditis produced an A wave of 25 per cent, but in 4 others the $A$ waves were of normal amplitude.

In 1963, the late systolic bulge was described by Benchimol, Legler, and Dimond as characteristic of subaortic stenosis, but in the same year Rörvik showed that it also occurred in some normal subjects. Tafur et al. (1964) consider the mid-systolic bulge more characteristic of subaortic stenosis.

Timing. In our own records, the A wave of the apex cardiogram coincided with the fourth heart 
sound or with the atrial component of the first heart sound in the phonocardiogram (as in the study of Benchimol and Dimond, 1963a). Coulshed and Epstein (1963) believe that the A wave of the apex cardiogram immediately precedes the fourth sound, but Orías and Braun-Menéndez (1939) are of the opinion that the A wave follows the fourth heart sound. Benchimol and Dimond (1963a) and Tabatznik (1964) stated that the A wave occurred 0.08 to 0.12 second after onset of the $P$ wave of the electrocardiogram and coincided with, or shortly preceded, the QRS wave in the electrocardiogram. Hartman and Snellen (1960) estimated the interval from the beginning of the $P$ wave of the electrocardiogram to the onset of the A wave of the apex cardiogram to be about 0.10 second. In concurrence with Luisada and Magri (1952), the A wave of the apex cardiogram was found in our records to follow the $P$ wave of the cardiogram at a definite time interval, in normal persons as well as in patients with $A-V$ block. In a study of 111 normal subjects, the interval between the peak of the $P$ wave of the electrocardiogram and the peak of the A wave of the apex cardiogram was 0.04 to 0.09 second (average 0.072 second) (Rörvik, 1963).

The isometric contraction time can be measured from the end of the $A$ wave to the $E$ point, and normally averages 0.03 second (with a range of from 0.03 to 0.06 second) (Benchimol and Dimond, 1963a). It was longer in the 8 out of 9 of those patients with subaortic stenosis in whom it could be measured (see Table).

Mechanism of Production of the $A$ Wave. The A wave arises from the ventricle and represents the impact of blood against the ventricular wall, as it fills rapidly when the atrium contracts in late diastole (Coulshed and Epstein, 1963). The fact that it represents atrial contraction can be proved by study of cases of complete heart block (Luisada and Magri, 1952), atrial flutter, and atrial tachycardia (Dimond, 1964). In all three examples the $P$ wave of the electrocardiogram is followed after a regular interval by an $\mathrm{A}$ wave in the apex cardiogram. Further proof is the disappearance of the A wave in atrial fibrillation. When the P-R interval of the electrocardiogram is increased, the $A$ wave of the apex cardiogram appears earlier. In the presence of atrial premature beats the P-R interval is decreased and the $A$ wave of the apex cardiogram moves closer to the systolic component of the apex cardiogram.

The A wave of the apex cardiogram is the result of atrial contraction, causing the blood to enter the ventricle. In contrast, the " $a$ " wave of the jugular venous pulse results from blood directed away from the ventricle (Hartman and Snellen, 1960) and only records right-sided events; the apex cardiogram is representative of left-sided events. The $A$ wave of the apex cardiogram coincides with the " $a$ " waves of the left atrium, right atrium, and pulmonary wedge curves (Benchimol and Dimond, 1963a; Coulshed and Epstein, 1963). It has also been shown that it occurs with the "a" wave of the left ventricular pressure curve (Coulshed and Epstein, 1963).

Dimond (1964) has demonstrated that in angina pectoris there exists a correlation between the amplitude of the $A$ wave of the apex cardiogram and the left ventricular end-diastolic pressure. In valvular aortic stenosis a fourth heart sound is only present when the left ventricular end-diastolic pressure is greater than $12 \mathrm{~mm}$. Hg (Goldblatt, Aygen, and Braunwald, 1962). In the presence of a fourth heart sound a significant $A$ wave is usually seen in the apex cardiogram. Rörvik (1963), however, noted occasional exceptions to this rule when he found that not all 13 of his cases of coronary disease with $A$ waves greater than 30 per cent had discernible fourth heart sounds. In our patients we found no correlation between the amplitude of the $A$ wave and ventricular end-diastolic pressure. It is, therefore, assumed that another factor must be involved in the expansion of the ventricle with atrial contraction. One possible explanation is that in the presence of subaortic stenosis the ventricular myocardium expands more readily than in normal subjects, as the atrium contracts.

\section{SUMMARY}

The apex cardiogram showed abnormally large $A$ waves in 8 out of 9 patients with idiopathic hypertrophic subaortic stenosis. The A waves were above normal width in 7 out of 8 patients. The isometric contraction time was prolonged in 8 of the 9 patients in whom this measurement could be made.

The height of the A wave showed no correlation with the end-diastolic left ventricular pressure; it also showed no correlation with the systolic gradient in the left ventricle.

While not all records in subaortic stenosis show a very large $A$ wave, its presence should alert the observer to the possibility of this diagnosis. A tall A wave may be related clinically to a palpable bulge just preceding the main apex impulse and thus producing a double pulsation at the apex.

I would like to thank Dr. Oscar Magidson for his advice and kind permission to use cases from the files of 
the Department of Cardiology at St. Vincent's Hospital, Los Angeles, California.

\section{REFERENCES}

Agress, C. M., Wegner, S., Bleifer, D. J., Lindsey, A., Van Houten, J., Schroyer, K., and Estrin, H. M. (1964). The common origin of precordial vibrations. Amer. $\mathcal{F}$. Cardiol., 13, 266.

Beilin, L., and Mounsey, P. (1962). The left ventricular impulse in hypertensive heart disease. Brit. Heart f., 24, 409.

Benchimol, A., and Dimond, E. G. (1962). The apex cardiogram in ischæmic heart disease. Brit. Heart f., 24, 581.

$\longrightarrow$, and - (1963a). The normal and abnormal apexcardiogram; its physiologic variation and its relation to intracardiac events. Amer. F. Cardiol., 12, 368.

- , and - (1963b). The apexcardiogram in normal older subjects and in patients with arteriosclerotic heart disease; effect of exercise on the "a" wave. Amer. Heart F., 65, 789.

—, Legler, J. F., and Dimond, E. G. (1963). The carotid tracing and apexcardiogram in subaortic stenosis and idiopathic myocardial hypertrophy. Amer. f. Cardiol., $11,427$.

Braunwald, E., Lambrew, C. T., Rockoff, S. D., Ross, J., Jr., and Morrow, A. G. (1964). Idiopathic hypertrophic subaortic stenosis. Circulation, 30, Suppl. 4. (Amer. Heart Ass. Monogr. No. 10).

Brock, R. (1957). Functional obstruction of the left ventricle (acquired aortic subvalvar stenosis). Guy's Hosp. Rep., 106, 221.

Coulshed, N., and Epstein, E. J. (1963). The apex cardiogram: its normal features explained by those found in heart disease. Brit. Heart F., 25, 697.
Dimond, E. G. (1964). Precordial vibrations; clinical clues from palpation. Circulation, 30, 284.

Eddleman, E. E., Willis, K., Reeves, T. J., and Harrison, T. R. (1953). The kinetocardiogram: I. Method of recording precordial movements. Circulation, 8, 269.

Goldblatt, A., Aygen, M. M., and Braunwald, E. (1962). Hemodynamic-phonocardiographic correlations of the fourth heart sound in aortic stenosis. Circulation, 26, 92.

Hartman, H., and Snellen, H. A. (1960). The apex cardiogram. In Proc. of the Third European Congress of Cardiology, Rome, 1960, Vol. 2, Part B, pp. 711-713. Excerpta medica.

Luisada, A. A., and Magri, G. (1952). The low frequency tracings of the precordium and epigastrium in normal subjects and cardiac patients. Amer. Heart f., 44, 545.

Marey, Etienne Jules (1878). La Méthode graphique dans les Sciences expérimentales et particulièrement en Physiologie et en Médecine. (The Graphic Method in Experimental Sciences and Especially in Physiology and Medicine). Masson, Paris.

Orias, Oscar, and Braun-Menćndez, Eduardo (1939). The Heart-Sounds in Normal and Pathological Conditions. Oxford University Press, London.

Rörvik, K. (1963). Apexcardiography, phonocardiography and ballistocardiography-their diagnostic and prognostic significance in coronary heart disease. Acta med. scand., 174, Suppl. 404.

Tabatznik, B. (1964). The genesis and clinical importance of the atrial and ventricular diastolic gallop. In The Theory and Practice of Auscultation, The Ninth Hahnemann Symposium, ed. Bernard L. Segal, pp. 126-143. The F. A. Davis Company, Philadelphia.

Tafur, E., Cohen, L. S., and Levine, H. D. (1964). The apex cardiogram in left ventricular outflow tract obstruction. Circulation, 30, 392. 